D.R. Bevan MB MRCP FFARCS, P. Fiset MD FRCPC, P. Balendran MB FFARCS, J.C. Law-Min MB FFARCS, A. Ratcliffe MB FFARCS, F. Donati MD PhD FRCPC

\title{
Pharmacodynamic behaviour of rocuronium in the elderly
}

This study compared the potency and time course of action of rocuronium (ORG 9426) in elderly and young patients during nitrous oxide-opioid anaesthesia. One hundred ASA physical status I-II patients (60, aged 65-80 yr, and 40, aged 20-45 yr) were studied by measuring the force of contraction of the adductor pollicis in response to train-of-four stimulation of the ulnar nerve. After induction of anaesthesia with thiopentone and maintenance with $\mathrm{N}_{2} \mathrm{O} / \mathrm{O}_{2}$ and fentanyl, rocuronium 120 . 160, 200, or $240 \mu \mathrm{g} \cdot \mathrm{kg}^{-1}$ was administered to determine doseresponse curves. When maximum block had been obtained, further rocuronium to a total of $300 \mu \mathrm{g} \cdot \mathrm{kg}^{-1}$ was given. Additional doses of $100 \mu \mathrm{g} \cdot \mathrm{kg}^{-1}$ were administered when the first twitch height $\left(T_{l}\right)$ had recovered to $25 \%$ control. At the end of surgery neuromuscular blockade was allowed, whenever possible, to recover spontaneously until $T_{1}$ was $90 \%$ of control before administration of neostigmine. There was no difference in the potency of rocuronium in the elderly and the younger patients. The $E D_{50}$ was $196 \pm 8$ (SEE for the mean) in elderly, vs $215 \pm 17 \mu \mathrm{g} \cdot \mathrm{kg}^{-1}$ in young patients (NS). When individual cumulative dose-response curves were constructed, the $E D_{50}$ was $203 \pm 7$ (SEM) and $201 \pm 10 \mu \mathrm{g} \cdot \mathrm{kg}^{-1}$ in the elderly and the young respectively (NS). However, the onset of maximum neuromuscular block was slower in the elderly $3.7 \pm 1.1$ (SD) vs $3.1 \pm 0.9 \mathrm{~min}, P<0.05$ ). The time to $25 \% T_{l}$ recovery was longer in the elderly $(11.8 \pm 8.1$ vs $8.0 \pm 6.5 \mathrm{~min}, P<$ $0.05)$ as was the recovery index, time from 25 to $75 \% T_{1}$ recovery (15.5 \pm 6.2 vs $11.2 \pm 4.9 \mathrm{~min}, P<0.05$ ). The duration of neuromuscular block after each maintenance dose was longer

\section{Key words}

ANAESTHESIA: geriatric;

NEUROMUSCULAR RELAXANTS: rocuronium (ORG 9426).

From the Department of Anaesthesia, Royal Victoria Hospital and McGill University, Montreal, Quebec, Canada.

Address correspondence to: Dr. D.R. Bevan, Department of Anaesthesia, Vancouver General Hospital, 910 West 10th Avenue, Vancouver, B.C., Canada V5Z 4E3.

Supported, in part, by a grant from Organon Inc. Accepted for publication 19th October, 1992. in the elderly $(P<0.01)$ and increased gradually with time. It is concluded that rocuronium is an intermediate-acting neuromuscular blocking drug with a similar potency in elderly and young patients, but the onset and recovery of neuromuscular blockade are slower in the elderly.

Cette étude compare la puissance et l'évolution temporelle de l'effet du rocuronium (ORG 9426) chez des patients âgés et des jeunes pendant une anesthésie au protoxyde d'azote associé à un opiacé. Cent patients ASA classes I-II $(60$ sujets de 60 à 80 ans et 40, de 20 à 40 ans) font l'objet de l'étude qui consiste à mesurer la force de contraction de l'adducteur court du pouce en réponse à la stimulation du nerf cubital au train de quatre. Après linduction de l'anesthésie au thiopental et le maintien au $\mathrm{N}_{2} \mathrm{O} / \mathrm{O}_{2}$ avec fentanyl, du rocuronium est administré aux doses de $120,160,200$ et $240 \mu \mathrm{g} \cdot \mathrm{kg}^{-1}$ pour déterminer la relation dose effet. Une fois le block maximum obtenu, on donne une dose supplémentaire de rocuronium jusqu'à un total de $300 \mu \mathrm{g} \cdot \mathrm{kg}^{-1}$. On ajoute des doses de $100 \mu \mathrm{g} \cdot \mathrm{kg}^{-l}$ dès que la première contraction $\left(T_{l}\right)$ revient à $25 \%$ du contrôle. $A$ la fin de la chirurgie, on laisse le block récupérer spontanément, lorsque c'est possible, jusqu'à ce que $T_{1}$ atteigne $90 \%$ du contrôle avant d'administrer de la néastigmine. On ne retrouve pas de différence de puissance pour le rocuronium entre les patients jeunes et les patients âgés. La DE 50 est de $196 \pm$ 8 (SEE pour la moyenne) chez les patients âgés vs $215 \pm 17$ $\mu \mathrm{g} \cdot \mathrm{kg}^{-1}$ chez les jeunes (NS). Lorsqu'on construit des courbes dose-effet individuelles cumulatives, la $D E_{50}$ est respectivement de $203 \pm 7$ (SEM) et de $201 \pm 10 \mu \mathrm{g} \cdot \mathrm{kg}^{-1}$ chez les personnes âgées et les jeunes (NS). Cependant le block neuromusculaire survient plus lentement chez le sujet âgé $(3,7 \pm 1,1(S D)$ vs $3,1 \pm 0.9 P<0,05)$. La période de recouvrement de $T_{I} \dot{a}$ $25 \%$ se prolonge dans le groupe âgé $(11,8 \pm 8,1$ vs $8,0 \pm 6,5$ min, $P<0,05)$ de même que lindex de récupération $(5,5 \pm$ $6,2$ vs $11,2 \pm 4,9 \mathrm{~min}, P<0,05)$. La durée du block neuromusculaire après chaque dose de maintien est plus longue pour le groupe âgé $(P<0,01)$ et augmente progressivement avec le temps. On conclut que le rocuronium est un myorelaxant à action intermédiaire dont la puissance ne differe pas chez les patients âgées et les jeunes. Son d'action débute plus lentement et sa durée de récupération est plus longue chez le sujet âgé. 
Rocuronium (ORG 9426) is an aminosteroidal neuromuscular blocking drug with an intermediate duration of action. Its major difference from vecuronium is its more rapid onset of action which is probably a result of its lower potency.' Studies in animals showed that rocuronium is about one fifth as potent as vecuronium and has insignificant cardiovascular effects. The duration of action was similar to vecuronium but its onset of block was about twice as rapid. ${ }^{2,3}$ In general, these effects have been confirmed in humans, ${ }^{4-6}$ although in one study the mean time to maximum effect was $4.6 \mathrm{~min} .{ }^{7}$ However, all these studies have been performed in young and middle aged adults.

Pharmacokinetic and pharmacodynamic studies of the nondepolarizing neuromuscular blocking drugs d-tubocurarine, ${ }^{8}$ metocurine, ${ }^{8}$ pancuronium,,${ }^{9-11}$ alcuronium, ${ }^{12}$ and vecuronium ${ }^{11,13,14}$ have shown prolonged duration of neuromuscular blockade and slower recovery from neuromuscular block in the elderly mainly as a result of decreased renal and hepatic elimination. There is conflicting evidence concerning the effects of atracurium. As the elimination of atracurium is mainly independent of liver and kidney function, age-related changes in organ function would not be expected to modify its pharmacological activity and this has been confirmed in two studies. ${ }^{15,16}$ However, one report suggested that the elimination of atracurium may be prolonged in the elderly as a result of an increase in volume of distribution. ${ }^{17}$ Doseresponse studies have shown that the potencies of atracurium, pancuronium and vecuronium are no different in the young from the elderly. ${ }^{18,19}$ However, haemodynamic changes with aging may cause delayed onset of neuromuscular blockade. ${ }^{20}$

Rocuronium is the first of the recently introduced neuromuscular blocking drugs which has an onset of action which is rapid enough to compete with succinylcholine to facilitate tracheal intubation. However, as the onset characteristics have only been described in younger subjects it seemed to be important to determine whether they were also present in the elderly and whether aging would lead to a longer duration of action which might prejudice the use of rocuronium in the elderly. Thus, the purpose of this study was to compare the pharmacodynamic behaviour of rocuronium in young and elderly patients.

\section{Methods}

The protocol was approved by the Hospital Ethics Committee. After informed consent had been obtained, 100 adult patients (60 aged 65-80 yr, and 40 aged 20-45 yr) ASA physical status I or II, scheduled for elective surgery were entered into the study. Patients with hepatic, renal, or neuromuscular disease were excluded. Other exclusion criteria included women of child-bearing poten- tial, abnormality of serum electrolyte concentrations, personal or family history of plasma cholinesterase deficiency, malignant hyperthermia, recent treatment with any medication known or suspected of interfering with neuromuscular function, and known allergy to benzyl alcohol, opioids or other medications used during anaesthesia.

Diazepam, $10 \mathrm{mg} \mathrm{po}$, was administered approximately one hour before the anticipated start of surgery. In the operating room, the ECG and $\mathrm{SpO}_{2}$ were monitored continuously, and arterial blood pressure was measured, noninvasively, every three minutes. Anaesthesia was induced with thiopentone, 2-8 $\mathrm{mg} \cdot \mathrm{kg}^{-1}$, and fentanyl, up to 4 $\mu \mathrm{g} \cdot \mathrm{kg}^{-1}$, and was maintained with $\mathrm{N}_{2} \mathrm{O} / \mathrm{O}_{2}$ and increments of fentanyl $(50-100 \mu \mathrm{g})$ as required.

The ulnar nerve was stimulated supramaximally using a Relaxograph (Datex Instrumentation Corp., Helsinki, Finland) and via surface electrodes at the wrist, with square-wave pulses of $0.2 \mathrm{msec}$ duration delivered at a frequency of $2 \mathrm{~Hz}$ for $2 \mathrm{sec}$ (train-of-four, TOF) and repeated every ten seconds. The hand and forearm were immobilized in a splint. The force of contraction of the adductor pollicis was measured with a force displacement transducer (Grass FT-10) and recorded on paper.

Patients received, by random allocation, one of four doses of rocuronium $\left(120,160,200\right.$, or $\left.240 \mu \mathrm{g} \cdot \mathrm{kg}^{-1}\right)$ within 1-2 min of the start of recording. When maximal block had been achieved (three consecutive $T_{1}$ responses of equal magnitude) a supplemental dose of rocuronium was given so that each patient had received a total of $300 \mu \mathrm{g} \cdot \mathrm{kg}^{-1}$. The trachea was intubated at maximal block or when $T_{1}$ was less than $10 \%$ of control During surgery additional doses of rocuronium were given, 100 $\mu \mathrm{g} \cdot \mathrm{kg}^{-1}$, whenever $T_{1}$ returned to $25 \%$ control. At the end of surgery, neuromuscular activity was allowed, whenever possible, to recover spontaneously until $T_{1}$ reached $90 \%$ control. At this time neostigmine, 20-40 $\mu \mathrm{g} \cdot \mathrm{kg}^{-1}$, and atropine were given if the TOF ratio was less than 0.7 .

Dose-response relationships were calculated for $T_{1}$ by linear regression of the logit transformation of twitch depression and the logarithm of rocuronium dose. These regression lines were used to determine the $\mathrm{ED}_{50}, \mathrm{ED}_{90}$, and $\mathrm{ED}_{95}$ values. Dose-response data were also obtained in each patient by analysis of the cumulative effect of the two doses given. The logit transformation of $T_{1}$ was plotted against the logarithm of the cumulative dose given, and the $\mathrm{ED}_{50}, \mathrm{ED}_{90}$, and $\mathrm{ED}_{95}$, were determined for each patient. The onset time was the interval between injection of rocuronium and maximal $T_{1}$ depression. The duration of block was defined as the time from the injection of the second dose until $T_{1}$ had recovered to $25 \%$ of control. The duration of action of maintenance doses 
TABLE I Demographic data

\begin{tabular}{lllll}
\hline Age $y r$ & M:F & Weight $\mathrm{kg}$ & Height cm & Duration min \\
\hline Young $(n=40)$ & & & & \\
$33.7 \pm 8.0$ & $30: 10$ & $70.5 \pm 12.8$ & $172.3 \pm 8.0$ & $78.0 \pm 39.4$ \\
Elderly $(n=60)$ & & & & \\
$71.6 \pm 4.2$ & $26: 34$ & $68.7 \pm 13.0$ & $162.2 \pm 12.0$ & $110.0 \pm 53.9$ \\
$P<0.001$ & $<0.01$ & NS & $<0.01$ & $<0.05$ \\
\hline
\end{tabular}

was defined as the interval between the injection of the maintenance dose of rocuronium (administered at a $\mathrm{T}_{1}$ of $25 \%$ of control), and the return of $T_{1}$ to $25 \%$ of control. After the final dose of rocuronium, the times at which $\mathrm{T}_{1}$ recovered to $10 \%, 25 \%, 50 \%, 75 \%$, and $90 \%$ were recorded and the recovery index $\left(25-75 \% \mathrm{~T}_{1}\right.$ recovery time) was calculated.

Values are presented, unless stated otherwise, as the mean $\pm \mathrm{SD}$. Statistical comparisons between the groups of young and elderly patients were performed using anal$y$ sis of variance, paired and unpaired Student's $t$ test, and Bonferroni's correction for multiple comparisons where appropriate. Dose-response curves were evaluated using regression analysis. Analysis of covariance was used to compare the regression lines. The $\mathrm{ED}_{50}, \mathrm{ED}_{90}$, and $\mathrm{ED}_{95}$ calculated by the single dose method are given as means \pm standard error of the estimate of the mean (SEE). The level of significance was set at $P<0.05$.

\section{Results}

Patients in the elderly group had a greater proportion of women, were shorter but not different in weight, and were undergoing longer procedures than those in the younger group (Table I).

The potency of rocuronium was similar in the young and old. The $\mathrm{ED}_{50}$, calculated by the single dose method, was $196 \pm 8$ (SEE) in the elderly and $215 \pm 17 \mu \mathrm{g} \cdot \mathrm{kg}^{-1}$ in young patients. When individual cumulative doseresponses were constructed the $\mathrm{ED}_{50}$ was $203 \pm 7$ (SEM) and $201 \pm 10 \mu \mathrm{g} \cdot \mathrm{kg}^{-1}$ (NS) in the elderly and young respectively (Table II). Although the dose-response curves appear to diverge there was no statistical difference in their slopes or position. Following the second dose of rocuronium (total $300 \mu \mathrm{g} \cdot \mathrm{kg}^{-1}$ ), the maximum block was not different between the two groups (Table III).

The onset of maximum block after the first and second doses of rocuronium was more rapid in the young than the elderly. There was no difference in the time to maximum block among the different doses of rocuronium. Recovery to $25 \% \mathrm{~T}_{1}$ was also more rapid in the young as was the recovery index (Table III). Maintenance doses,
TABLE II Potency of rocuronium in young and elderly patients

\begin{tabular}{lll}
\hline & $\begin{array}{l}\text { Single dose method } \\
\mu g \cdot \mathrm{kg}^{-1} \\
(\text { mean } \pm S E E)\end{array}$ & $\begin{array}{l}\text { Cumulative method } \\
\mu g \cdot \mathrm{kg}^{-1} \\
(\text { mean } \pm S E M)\end{array}$ \\
\hline Young & & \\
$\mathrm{ED}_{50}$ & $215 \pm 17$ & $201 \pm 10$ \\
$\mathrm{ED}_{90}$ & $419 \pm 34$ & $329 \pm 18$ \\
$\mathrm{ED}_{95}$ & $521 \pm 42$ & $390 \pm 24$ \\
Elderly & & \\
$\mathrm{ED}_{50}$ & $196 \pm 8$ & $203 \pm 7$ \\
$\mathrm{ED}_{90}$ & $315 \pm 14$ & $311 \pm 11$ \\
$\mathrm{ED}_{95}$ & $369 \pm 16$ & $367 \pm 14$ \\
\hline
\end{tabular}

TABLE III Times to maximum block after first $\left(t_{1}\right.$ max) and second $\left(t_{2}\right.$ max) doses of rocuronium, times to $25 \%$ recovery of $T_{1}$, recovery index, and maximum block after rocuronium $300 \mu \mathrm{g} \cdot \mathrm{kg}^{-1}$

\begin{tabular}{lllll}
\hline$\iota_{1} \max \min$ & $t_{2}$ max $\min$ & $\begin{array}{l}\max _{2} \text { block } \\
\%\end{array}$ & $\begin{array}{l}25 \% \text { recovery } \\
\min \end{array}$ & $\begin{array}{l}\text { Recovery } \\
\text { index min }\end{array}$ \\
\hline Young & & & & \\
$\begin{array}{l}3.13 \pm 0.89 \\
n=40\end{array}$ & $2.7 \pm 1.0$ & $81.4 \pm 17.7$ & $8.0 \pm 6.5$ & $11.2 \pm 4.9$ \\
& 40 & 40 & 40 & 22 \\
Elderly & & & & \\
$3.72 \pm 1.1$ & $3.9 \pm 1.5$ & $84.6 \pm 16.3$ & $11.8 \pm 8.1$ & $15.5 \pm 5.7$ \\
$n=60$ & 60 & 60 & 60 & 41 \\
$P<0.01$ & $<0.001$ & NS & $<0.05$ & $<0.01$ \\
\hline
\end{tabular}

$100 \mu \mathrm{g} \cdot \mathrm{kg}^{-1}$, lasted for longer in the elderly (Figure). In those patients who received at least six increments of rocuronium and for whom data collection was complete at each interval ( $n=30$ after combining both groups) there was a gradual increase in duration of each maintenance dose from a mean of $11.9 \pm 4.1 \mathrm{~min}$ of the first two increments to $16.5 \pm 6.7 \mathrm{~min}$ following the fifth increment $(P<0.0001)$.

\section{Discussion}

This study demonstrates that rocuronium is a neuromuscular blocking drug of low potency $\left(\mathrm{ED}_{50} 200 \mu \mathrm{g} \cdot \mathrm{kg}^{-1}\right)$ and intermediate duration (time to $25 \%$ recovery after $1.5 \times \mathrm{ED}_{50}-8-12 \mathrm{~min}$, recovery index 11-16 min) and with a rapid (3-4 $\mathrm{min}$ ) onset of block compared with other non-depolarizing muscle relaxants. In the elderly, the onset and recovery of block are slightly slower than in the young, but the potency is similar.

In the present study, doses from 120 to $240 \mu \mathrm{g} \cdot \mathrm{kg}^{-1}$ were given initially to establish dose-response relationships. The calculated $\mathrm{ED}_{50}\left(215\right.$ and $196 \mu \mathrm{g} \cdot \mathrm{kg}^{-1}$ in the young and elderly respectively) was within that range. 


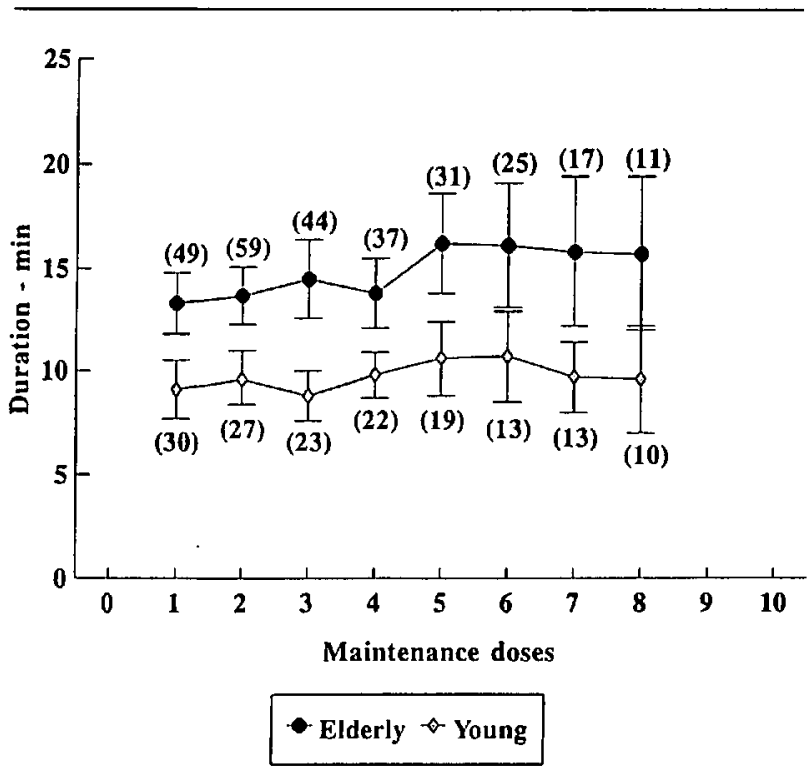

FIGURE Duration of maintenance doses administered at $25 \% \mathrm{~T}_{1}$ recovery. Data are included from all patients $(n)$ at each interval.

Thus, the accuracy of the $\mathrm{ED}_{50}$ estimates is greater than that of the $\mathrm{ED}_{90}$ and $\mathrm{ED}_{95}$ values $\left(315-521 \mu \mathrm{g} \cdot \mathrm{kg}^{-1}\right.$ which are outside the dose range tested, and are extrapolations. To obtain more accurate estimates of the $\mathrm{ED}_{90}$ and $\mathrm{ED}_{95}$, a two-dose cumulative technique was used, similar to a method used for atracurium. ${ }^{21}$ The two-dose technique was found to yield, for atracurium, results which were comparable with those obtained with the single-dose method. ${ }^{21}$ This is in contrast to giving four to six successive doses of atracurium or vecuronium, which tends to overestimate the $\mathrm{ED}_{90}$ and $\mathrm{ED}_{95},{ }^{22-24}$ probably because some distribution and/or elimination is more likely to occur when a large number of doses are administered over a longer time.

In the present study, and irrespective of the method used, the $\mathrm{ED}_{50} \mathrm{~s}$ were similar in the young and elderly. However, because the $\mathrm{ED}_{90}$ and $\mathrm{ED}_{95}$ obtained by the single-dose technique were extrapolations, the values were similar in the young $\left(E_{95}=390 \mu \mathrm{g} \cdot \mathrm{kg}^{-1}\right)$ and elderly $\left(\mathrm{ED}_{95}=367 \mu \mathrm{g} \cdot \mathrm{kg}^{-1}\right)$ adults.

These results agree with previous studies of rocuronium in young adults ${ }^{4-6}$ and suggest that it is an intermediate-duration muscle relaxant with a more rapid onset of action than vecuronium ${ }^{25-27}$ or atracurium ${ }^{26,27}$ but longer than succinylcholine. ${ }^{28}$ The longer duration of action of metocurine, ${ }^{8}$ d-tubocurarine, ${ }^{8}$ and pancuronium $^{9}$ in the elderly has been associated with decreased plasma clearance and prolonged elimination half-life. Pharmacokinetic studies of rocuronium have now been performed in young and elderly patients. In the young, rocuronium was found to be similar to vecuronium. The liver appears to be a more important route of elimination than the kidney: only one third of the administered dose appeared in the urine within $24 \mathrm{hr}^{5}$ The duration of action of vecuronium is prolonged in the elderly ${ }^{13}$ but, surprisingly, some studies have failed to provide a pharmacokinetic explanation. Rupp et al. examined the pharmacokinetic and pharmacodynamic behaviour of vecuronium after discontinuing its administration by infusion. They showed that although plasma clearance of vecuronium was reduced in the elderly, this was matched by a decreased volume of distribution, and the terminal half-life was unaffected. ${ }^{11}$ More recently, it has been demonstrated that, after bolus injection, the plasma clearance of vecuronium is reduced and its terminal half-life prolonged in the elderly. ${ }^{14}$ Similar findings were given in a preliminary report of the pharmacokinetic behaviour of rocuronium. ${ }^{29}$ The most likely reason for the prolonged duration in the elderly is a decrease in renal and hepatic perfusion associated with aging.

The onset of action of rocuronium at the adductor pollicis is more rapid than for other currently available non-depolarizing neuromuscular blocking drugs except for gallamine. ${ }^{30}$ Rocuronium is also the least potent nondepolarizing relaxant and Bowman et al. have demonstrated a relationship between potency and the onset time for a series of aminosteroidal compounds. ${ }^{1}$ The reason is related to the large proportion of receptors which need to be occupied before the development of neuromuscular block - i.e., the "margin of safety." 11 This is more easily and rapidly achieved by providing large numbers of molecules of a low potency compound. The onset time will be more rapid at higher doses - 2-3 $\times \mathrm{ED}_{95}$. Under these conditions, with onset defined as the time to complete block, basic principles indicate that onset must be more rapid with higher doses. In addition, the onset of rocuronium blockade, like pancuronium, ${ }^{32}$ is directly related to age. However, to provide ideal conditions for tracheal intubation the onset of action of neuromuscular blocking drugs at the larynx is more important than at the thumb. Recently, it has been demonstrated that the onset of action of vecuronium ${ }^{33}$ and succinylcholine ${ }^{34}$ is more rapid at the laryngeal adductor muscles than at the adductor pollicis. Consequently, it is likely that good intubating conditions following equipotent doses are likely to be achieved earlier after rocuronium than after vecuronium. Successful tracheal intubation has been reported within one minute after rocuronium, 1000 $\mu \mathrm{g} \cdot \mathrm{kg}^{-1} .^{5}$ Preliminary studies suggest that intubating conditions after rocuronium, $600 \mu \mathrm{g} \cdot \mathrm{kg}^{-1}$, may match those following succinylcholine, $1 \mathrm{mg} \cdot \mathrm{kg}^{-1} \cdot{ }^{35}$ However, succinylcholine has the additional advantage of rapid recovery which is not matched by rocuronium. 
In conclusion, it has been demonstrated that rocuronium is an intermediate-acting neuromuscular blocking drug with a rapid onset of action. Onset and recovery are delayed slightly in the elderly. Further studies are required to determine its place to facilitate tracheal intubation.

\section{References}

1 Bowman WC, Rodger IW, Houston J, Marshall RJ, McIndewar $L I$. Structure:action relationships among some desacetoxy analogues of pancuronium and vecuronium in the anesthetized cat. Anesthesiology 1988; 69: 57-62.

2 Muir AW, Houston J, Green KL, Marshall RJ, Bowman WC, Marshall IG. Effects of a new neuromuscular blocking agent (ORG 9426) in anaesthetized cats and pigs and in isolated nerve-muscle preparations. Br J Anaesth 1989; 63: $400-10$.

3 Cason B, Baker DG, Hickey RF, Miller RD, Agoston S. Cardiovascular and neuromuscular effects of three steroidal neuromuscular blocking drugs in dogs (ORG 9616, ORG 9426, ORG 9991). Anesth Analg 1990; 70: 382-8.

4 Wierda JMKH, De Wit APM, Kuizenga K, Agoston S. Clinical observations on the neuromuscular blocking action of ORG 9426, a new steroidal non-depolarizing agent. $\mathrm{Br} \mathrm{J}$ Anaesth 1990; 64: 521-3.

5 Weirda JMKH, Kleef UW, Lambalk LM, Kloppenburg $W D$, Agoston $S$. The pharmacodynamics and pharmacokinetics of ORG 9426, a new non-depolarizing neuromuscular blocking agent, in patients anaesthetized with nitrous oxide, halothane and fentanyl. Can J Anaesth 1991; 38: 430-5.

6 Foldes FF, Nagashima $H$, Nguyen HD. Schiller WS, Mason MM, Ohta $Y$. The neuromuscular effects of ORG 9426 in patients receiving balanced anesthesia. Anesthesiology 1991; 75: 191-6.

7 Quill TJ, Begin M, Glass PSA, Ginsberg B, Gorback MS. Clinical responses to ORG 9426 during isoflurane anesthesia. Anesth Analg 1991; 72: 203-6.

8 Matteo RS, Backus WW, McDaniel DD, Brotherton WP, Abraham R, Diaz J. Pharmacokinetics and pharmacodynamics of $d$-tubocurarine and metocurine in the elderly. Anesth Analg 1985; 64: 23-9.

9 McLead K, Hull CJ, Watson MJ. Effects of ageing on the pharmacokinetics of pancuronium. Br J Anaesth 1979; 51: 435-8.

10 Duvaldestin P, Saada J, Berger JL, D'Hollander A, Desmonts $J M$. Pharmacokinetics, pharmacodynamics, and dose-response relationships of pancuronium in control and elderly subjects. Anesthesiology 1982; 56: 36-40.

11 Rupp SM, Castagnoli KP, Fisher DM, Miller RD. Pancuronium and vecuronium pharmacokinetics and pharmacodynamics in younger and elderly adults. Anesthesiology $1987 ; 67: 45-9$.
12 Kent AP, Hunter JM. Pharmacodynamics of alcuronium in the elderly. $\mathrm{Br} \mathrm{J}$ Anaesth 1990; 64: 385P-386P.

13 D'Hollander A, Massaux F, Nevelsteen M, Agoston $S$. Age-dependent dose-response relationship of ORG NC45 in anaesthetized patients. Br J Anaesth 1982; 54: 653-7.

14 Lien CA, Matteo RS, Ornstein E, Schwartz AE, Diaz J. Distribution, elimination, and action of vecuronium in the elderly. Anesth Analg 1991; 73: 39-42.

15 D'Hollander AA, Luyckx C, Barvais L, De Ville A. Clinical evaluation of atracurium besylate requirement for a stable muscle relaxation during surgery: lack of age-related effects. Anesthesiology 1983; 59: 237-40.

16 Beattie WS, Buckley DN, Deguzman C, Hewson JR, Forrest $J B$. The effect of age on the duration of block produced by bolus injection of atracurium. Can $\mathbf{J}$ Anaesth 1988; 35: S118-S119.

17 Kitts JB, Fisher DM, Canfell PC, et al. Pharmacokinetics and pharmacodynamics of atracurium in the elderly. Anesthesiology 1990; 72: 272-5.

18 O'Hara DA, Fragen RJ, Shanks CA. The effects of age on the dose-response curves for vecuronium in adults. Anesthesiology 1985; 63: 542-4.

19 Bell PF, Mirakhur RK, Clarke RSJ. Dose-response studies of atracurium, vecuronium and pancuronium in the elderly. Anaesthesia 1989; 44: 925-7.

20 Donati $F$. Onset of action of relaxants. Can J Anaesth 1988; 35: S52-S58.

21 Meretoja OA, Wirtavuori $K$. Two-dose technique to create an individual dose-response curve for atracurium. Anesthesiology 1989; 70: 732-6.

22 Fisher $D M$, Fahey $M R$, Cronnelly $R$, Miller $R D$. Potency determination for vecuronium (ORG NC45): comparison of cumulative and single-dose techniques. Anesthesiology 1982; 57: 309-10.

23 Gibson FM, Mirakhur RK, Lavery GG, Clarke RSJ. Potency of atracurium: a comparison of single dose and cumulative dose techniques. Anesthesiology 1985; 62: 657-9.

24 Gibson FM, Mirakhur RK, Clarke RSJ, Lavery GG. Comparison of cumulative and single bolus dose techniques for determining the potency of vecuronium. $\mathrm{Br} \mathrm{J}$ Anaesth 1985; 57: 1060-2.

25 Casson $W R$, Jones $R M$. Vecuronium induced neuromuscular blockade. The effect of increasing dose on speed of onset. Anaesthesia 1986; 41: 354-7.

26 Gramstad L, Lilleaasen P, Minsaas B. Onset time and duration of action for atracurium, ORG NC45 and pancuronium. Br J Anaesth 1982; 54: 827-30.

27 Robertson EN, Booij LHD, Fragen $R$, Crul JF. Clinical comparison of atracurium and vecuronium (ORG NC 45). Br J Anaesth 1983; 55: 125-9.

28 Bevan JC, Popovic V, Baxter MRN, Donati F, Bevan DR. Onset of succinylcholine and vecuronium neuromuscular 
blockade in children during narcotic anaesthesia. Can $\mathbf{J}$ Anaesth 1991; 38: A83.

29 Matteo RS, Ornstein E, Schwartz AE, et al. Pharmacokinetics and pharmacodynamics of ORG9426 in elderly surgical patients. Anesthesiology 1991; 75: A1065.

30 Kopman AF. Pancuronium, gallamine, and d-tubocurarine compared: is speed of onset inversely related to drug potency? Anesthesiology 1989; 70: 915-20.

31 Paton WDM. Waud DR. The margin of safety of neuromuscular transmission. J Physiol 1967; 191: 59-90.

32 Donati $F$, Bevan $D R$. The influence of patient's sex, age and weight on pancuronium onset time. Can Anaesth Soc J 1986; 33: S86.

33 Donati F, Meistelman C, Plaud B. Vecuronium neuromuscular blockade at the adductor muscles of the larynx and adductor pollicis. Anesthesiology 1991; 74: 833-7.

34 Meistelman C, Plaude B, Donati F. Neuromuscular effects of succinylcholine on the vocal cords and adductor pollicis muscles. Anesth Analg 1991; 73: 278-82.

35 Dubois $M$, Shearrow T, Tran D, et al. ORG 9426 used for endotracheal intubation: a comparison with succinylcholine. Anesthesiology 1991; 75: A1066. 